\section{A festa do discurso: discurso e contexto sócio-histórico}

The discourse party: discourse and socio-historical context

José Luiz FIORIN (USP)

jolufi@uol.com.br

Recebido em: 17 de dez. de 2019. Aceito em: 05 de fev. de 2019.
FIORIN, José Luiz. A festa do discurso: discurso e contexto sócio-histórico.

Entrepalavras, Fortaleza, v. 10, n. esp., p. 12-26, mai. 2020. DOI: 10.22168/2237-6321-7esp1800

Resumo: Este trabalho apresenta os conteúdos tratados na tese de livredocência de Diana Luz Pessoa de Barros, intitulada A festa do discurso. Teoria do discurso e análise de redações de vestibulandos, ressaltando e analisando sua principal contribuição teórica: o exame das relações entre discurso e contexto sócio-histórico, ou seja, sua proposta de integração do que era chamado análise interna e análise externa. A questão central da tese é, portanto, a proposta de desenvolvimento de uma teoria do discurso capaz de conciliar a análise do texto, como sistema de regras capazes de explicar sua organização imanente - uma abordagem interna -, com o exame da inclusão contextual do texto - uma abordagem externa. A inserção numa classe social é, segundo a autora, o elemento central para estabelecer as relações entre discurso e contexto sóciohistórico. $\mathrm{Na}$ análise de redações de vestibulandos, Diana Pessoa de Barros mostra como se concretiza sua proposta teórica.

Palavras-chave: Texto. Contexto. Intertextualidade. Historicidade. 
Abstract: This paper discusses some topics raised by Diana Luz Pessoa de Barros in her work entitled The discourse party. Discourse theory and the analysis of writing assignments of University entrance examinations, with the purpose of highlighting and analyzing her main theoretical contribution: the investigation of the relations between discourse and socio-historical context. These relations are considered to be the outcome of an integration of what was then called internal and external approaches. The dissertation aims at developing a discourse theory that can reconcile, on the one hand, text analysis as a rule system able to explain its immanent organization (the internal approach), with, on the other hand, the analysis of the contextual insertion of any given text (the external approach). Social class insertion is taken to be the key element to relate discourse and socio-historical context. By analyzing writing assignments of University entrance examinations, Diana Pessoa de Barros demonstrates how to implement her theoretical proposal.

Keywords: Text. Context. Intertextuality. Historicity.

Você olha para as coisas que existem e pergunta: "Por quê?" Eu sonho com as que nunca existiram e pergunto: "Por que não?" Bernard Shaw

Em 1985, Diana Luz Pessoa de Barros fez concurso de livre-docência na Universidade de São Paulo. Nele, apresentou a tese A festa do discurso. Teoria do discurso e análise de redações de vestibulandos. Essa tese, infelizmente, nunca foi publicada integralmente. Tem ela dois tomos: o primeiro é teórico, tem a finalidade de apresentar uma visão de conjunto da teoria semiótica e de contribuir para o seu desenvolvimento; o segundo analisa redações de vestibular. Só o primeiro volume foi publicado, com o nome de Teoria do Discurso. Fundamentos semióticos (1988).

Nele, há diversas contribuições para o adiantamento da semiótica, especialmente no delineamento de uma sintaxe do discurso, principalmente no que diz respeito ao estudo das relações entre enunciador e enunciatário; no estabelecimento dos percursos e configurações das paixões; no exame da coerência textual, etc. No entanto, neste texto, não trataremos desses elementos.

É importante considerar, porém, que a não publicação da integralidade da tese fez esse livro ser visto como uma apresentação da semiótica, deixando, a meu ver, na sombra, sua principal contribuição teórica: o exame das relações entre discurso e contexto sócio-histórico, ou seja, uma proposta de integração do que era chamado análise interna e análise externa. Isso era, na época, uma proposta inovadora, pois, nos círculos semióticos, tinha-se uma ideia um tanto quanto redutora do princípio de imanência e, portanto, só a análise interna tinha lugar. Aliás, é inovadora até hoje em termos de semiótica no mundo. 
10 (esp.) $12-26$ mai. 2020
A proposta de Diana Luz Pessoa de Barros não viola o princípio da imanência. Ela propõe que essa integração se dá por meio da enunciação, que não seria apenas uma instância de mediação entre as estruturas narrativas e as estruturas discursivas, mas também entre o discurso e o contexto sócio-histórico de sua produção e de sua recepção. A questão central da tese é, portanto, a proposta de desenvolvimento de uma teoria do discurso capaz de conciliar a análise do texto, como sistema de regras capazes de explicar sua organização imanente - uma abordagem interna - , com o exame da inserção contextual do texto uma abordagem externa.

A pesquisadora começa a apresentação de sua proposta pela análise das estruturas narrativas e discursivas da enunciação. Os papéis temáticos de enunciador e de enunciatário constituem uma espécie de neutralização de dois percursos temáticos da configuração "enunciação": o percurso da produção e o da comunicação. Os papéis de enunciador e de enunciatário, aquele que comunica e aquele que recebe e interpreta a comunicação, estão no percurso da comunicação, enquanto o de sujeito da enunciação, aquele que produz o enunciado, sincretismo de enunciador e de enunciatário, está no percurso da produção. Depois de analisar minuciosamente esses esquemas narrativos e seu revestimento discursivo, Diana Luz Pessoa de Barros conclui que é a semântica discursiva o lugar, por excelência, em que "a enunciação e as formações ideológicas que a sustentam mostram-se na escolha dos percursos figurativos e temáticos e nas relações metafóricas e metonímicas que unem as várias isotopias" (I, p. 225).

A enunciação, ao criar o enunciado, institui também o enunciador e o enunciatário. Esses dois papéis temáticos, sincretizados no sujeito da enunciação, produzem o discurso-objeto e, por meio dele, podemos refazer a imagem do fabricante e da fabricação (I, p. 229).

No entanto, a análise interna, capaz de recompor a competência modal e a perfórmance do sujeito da enunciação e de fornecer indicações sobre os valores, não é suficiente para determinar, realmente, os valores de que o discurso é suporte e veículo. O sujeito da enunciação recebe-os de um destinador-manipulador e, portanto, sua definição depende de informações sobre esse destinador-manipulador de que provêm. Esse destinador determina as condições de produção e de recepção dos textos. Ele é a origem dos valores do sujeito da enunciação, sendo, portanto, um destinador sócio- histórico (ou psico-sócio-histórico). A autora considera o produtor e o receptor- interpretante fonte e destino dos 
valores do discurso (I, p. 235). "Determinar os destinadores do sujeito da enunciação corresponde a inserir o texto no contexto de uma ou mais formações ideológicas, que lhe atribuem, no fim das contas, o sentido" (I, p. 231). O desdobramento polêmico da narrativa, em percurso do sujeito e do antissujeito, permite situar e esclarecer os confrontos sociais em que se assentam os discursos. Sempre há por trás do enunciado uma ou mais formações ideológicas, que é preciso determinar.

Não se trata, como esclarece Diana Luz Pessoa de Barros, de analisar o sujeito ontológico, mas de "refazer os caminhos narrativos do destinador-manipulador e do destinador-julgador, assim como os percursos temáticos de produtor e de receptor-interpretante, pelo recurso aos textos que formam o contexto do discurso em questão" (I, p. 232). O problema do contexto é pensado em termos de relações intertextuais. O contexto é sempre discursivo, não se confunde com o "mundo das coisas". Verifica-se assim que a autora respeita o princípio de imanência, caro à semiótica.

O contexto é um texto maior, uma totalidade de significação, em cujo interior cada texto ganha sentido. "O sentido do texto depende do sentido do texto-contexto em que se integra" (I, p. 233). Em última instância, a cultura é um macrotexto que dá sentido aos diferentes textos. Entretanto, a análise semiótica de um texto não precisa reconstruir toda a cultura, mas deve determinar suas relações intertextuais mais evidentes. Trata-se de uma intertextualidade contextual. A intertextualidade é, pois, a relação dos textos que constituem o contexto com o texto objeto de análise. "A análise de outros textos do discurso em exame faz aceder aos fatores sóciohistóricos constitutivos da enunciação" (I, p. 234).

As dificuldades para realizar esse trabalho são a delimitação do contexto a ser estudado e a possibilidade de perder-se no macrotexto da cultura ou na diversidade de posições teóricas divergentes para explicar fatos da história ou da ideologia.

Diana Pessoa de Barros enfrenta essas duas dificuldades. A primeira é a questão da delimitação do contexto. Sem uma seleção desses discursos contextuais, a análise seria impossível. Evidentemente, recortes diferentes podem ser obtidos e um mesmo discurso pode ser lido em contextos diferentes. A verdade, porém, é que os textos fornecem pistas para sua inserção contextual (I, p. 235), o que significa que o texto pode ser inserido em contextos diversos, que, no entanto, são em número limitado. 
v. 10 (esp.)

$12-26$

mai.

2020

A pesquisadora distingue três tipos de contexto. O primeiro, mais imediato, chamado contexto situacional, é constituído por textos claramente metalinguísticos, em relação ao texto que contextualizam. Tomam o texto em análise como objeto de sua metalinguagem natural ou científica.

Esse tipo de contexto caracteriza a situação de enunciação espacialmente e temporalmente, servindo para localizar, no tempo e no espaço, o produtor e o receptor e, a partir daí, o sujeito da enunciação. Determina o que o enunciador pensa de seu discurso, do enunciatário, dos objetivos da produção, do ato de produzir, assim como as razões que levaram à fabricação do texto - cumprir uma tarefa escolar, ser aprovado no vestibular, ser reconhecido pela crítica, cumprir uma obrigação acadêmica, mostrar altos objetivos patrióticos ou preocupação com o desenvolvimento da ciência, e assim por diante (I, p. 236).

Nesse contexto, entram todos os paratextos e textos assemelhados (entrevistas, prefácios, posfácios, introduções, texto críticos, traduções, comentários, propostas de redação, etc.).

O segundo tipo de contexto é denominado contexto interno. Ele destina-se a reconstituir o caráter idioletal do texto, ou seja, determina os elementos ideológicos e linguísticos que caracterizam o sujeito da enunciação (I, p. 236). Um exemplo é a relação de um romance com os demais romances do mesmo autor.

O terceiro tipo é o contexto externo, que indica os valores que o sujeito da enunciação manipula, sejam eles de classe, de época, de cultura (I, p. 237).

A extensão desse contexto é grande e fronteiras são estabelecidas com critérios diversificados: de tempo, em "o romance da década de 70", de espaço, em "a literatura do Nordeste", de tempo e espaço, em "a literatura brasileira no início do século", de tema, de grupo profissional e muitos outros (I, p. 237).

O texto fornece indicações de todos esses contextos, principalmente no nível discursivo, bem como ao repetir, simular ou atacar outros discursos.

O denominador comum que permite caracterizar o sujeito da enunciação do ponto de vista sócio-histórico, a que se acrescentam as outras determinações contextuais, é a classe ou fração de classe a que pertencem o produtor e o receptor do texto (I, p. 237).

A autora vai então definir o que é classe social. Para ela, não interessam as concepções economicistas de classe social, ou seja, 
"aquelas que consideram as classes sociais determinadas apenas pelas relações econômicas, por ser essa definição de classe muito pobre paras caracterizar o produtor e o receptor do discurso" (I, p. 238). Adota a definição de classe dada por Poulantzas como o efeito de um conjunto de estruturas e de suas relações no nível econômico, político e ideológico. A classe pode ser identificada em qualquer nível, embora sua definição se reporte ao conjunto dos níveis (I, p. 240). Como se vê, a autora adota uma definição marxista, porém não economicista de classe social.

Se as classes são "efeitos da estrutura global no domínio das relações sociais", como diz Poulantzas:

podem-se conceber o produtor e o receptor do sujeito da enunciação como suportes dessa teia de relações econômicas, políticas e ideológicas, cuja determinação permite inscrever o discurso no contexto sócio-histórico de produção e de recepção (I, p. 242).

A apreensão das relações sociais e das estruturas que a definem se faz por meio de textos, pelo recurso à intertextualidade. Insistese no fato de que a autora não abandona o princípio de imanência, característica básica da semiótica.

Em seguida, Diana Pessoa de Barros vai definir o que é ideologia. Não adota a concepção de Marx de que a ideologia é falsa consciência, mas a de Gramsci de que a ideologia é visão de mundo.

Uma visão de mundo é um sistema de valores que define regras e normas de conduta social. Define-se em relação às classes sociais e suas práticas, pois cada visão de mundo diz respeito a um dado grupo, cujos membros compartilham os mesmos valores, pensam e agem de maneira semelhante. Evidentemente, a ideologia dominante, que é a da classe dominante, tem a função de ocultamento e dissimulação. No entanto, adotar a ideologia como visão de mundo permite mostrar que há diferentes saberes e modos de pensar relacionados às diversas classes e reconhecer contradições na maneira de ver o mundo. Embora a língua reflita esses diversos valores, é no discurso que se instalam as posições ideológicas distintas.

O texto é o lugar primordial em que se organizam procedimentos que permitem recriar o mundo, mostrando outras verdades e, assim, é o lugar em que a originalidade e a criatividade se deixam ver de forma mais evidente.

Em seguida, a pesquisadora apresenta sua análise das redações de vestibulandos, que concretiza essas ideias teóricas. Portanto, seu estudo, ao fim e ao cabo, pretende caracterizar linguística e ideologicamente o jovem que se candidata a um curso superior. 
10 (esp.)

$12-26$

mai.

2020

A FUVEST forneceu à pesquisadora 10\% das redações do vestibular de 1982. Foram convocados para a segunda fase, quando se realiza a prova de redação, 27.260 candidatos. Compareceram 24.239 concorrentes. Das cerca de 2.500 redações fornecidas pela FUVEST, Diana Pessoa de Barros analisou detidamente 534 e leu mais de 1.000. As redações analisadas foram selecionadas aleatoriamente e repartidas da seguinte forma: 251 da área de Humanidades, 145 de Ciências Biológicas e 139 de Ciências Exatas e Tecnologia. Dessa forma, ela procurou manter a proporção entre o número de candidatos por área e o total de vestibulandos da segunda fase. O número é satisfatório, pois, no restante do material, reiteram-se os tipos narrativos e as organizações temáticas e figurativas.

A proposta de redação foi a seguinte:

Suponha que você foi surpreendentemente convidado para uma festa de pessoas que mal conhece. Conte, num texto em prosa, o que teria ocorrido, imaginando também os pormenores da situação. Não deixe de transmitir suas possíveis reflexões e impressões. Evite expressões desgastadas e ideias prontas.

A análise narrativa é minuciosa. Segmentando as narrativas por critérios de mudança espaço-temporal, a história foi dividida em três sequências: sequência inicial, (antes da festa); sequência da festa (durante a festa) e sequência final (depois da festa). As sequências inicial e final passam-se em casa e o espaço da festa é outro.

Tendo analisado as estruturas narrativas, determinaram-se onze tipos narrativos. Os tipos I, II e III correspondem a aproximadamente $65 \%$ das redações. O tipo I:

conta a história de alguém que, estando triste em casa, recebeu um convite para uma festa de 'desconhecidos', aceitou com alegria, mas, na festa, não conseguiu a satisfação esperada, por razões diversas, voltando para casa, de novo infeliz (II, p. 263).

O tipo II inverte a situação: "trata-se de alguém que estava satisfeito em casa, recebeu o convite com apreensão, mas, na festa, se divertiu muito e voltou para casa contente" (II, p. 263). O tipo III é uma variante do tipo I. Diferencia-se apenas pelo fato de que a pessoa convidada está bem em casa, não quer aceitar o convite, mas precisa fazêlo. Repetem-se o fracasso e a insatisfação de I (II, p. 263). Nesse tipo, a festa é um fracasso já previsto e esperado, que apenas vem corroborar a imagem negativa que se faz de quem convida ou de si mesmo. Os tipos I e III são narrativas de fracasso, enquanto as do tipo II são de sucesso. 
As primeiras correspondem a 33,33\% do total de redações, enquanto as segundas, a 32,02\%. Os percursos narrativos assemelham-se bastante nos três tipos. Se a essas semelhanças se acresce a busca dos mesmos valores, verifica-se quão pequena é a diferença das redações de mais de 65\% dos vestibulandos (II, p. 336-337).

Os outros 35\% repartem-se por nove grupos, se aí forem incluídas as redações fora do tema. As redações dos tipos IV e IX, que perfazem 3,74\%, desenvolvem-se essencialmente na dimensão cognitiva dos absurdos, dos sonhos, das relações entre imaginação e realidade (tipo IV) ou nas festas apenas imaginadas (tipo IX).

O tipo V (6,7\% do total) contém as redações em que não há a sequência da festa, apresentando os textos apenas a questão da aceitação ou da recusa do convite. Essas redações contam a história das dúvidas do sujeito, indeciso entre aceitar ou não o convite. Elas terminam com a aceitação ou a recusa do sujeito, o que permite agrupá-las em dois subtipos (II, p. 340).

Mais frequentes são as redações dos grupos VII (7,11\%) e VIII (3,37\%), que também são cognitivas e discutem a questão do parecer e do ser e do saber e do não saber. As do tipo VII são as redações de logro, surpresa, cilada, engodo, em que os conhecimentos e as crenças do sujeito, depois da modalização do saber, interpretamse como errôneos e enganosos. O saber diz respeito ao tipo de festa (por exemplo, festa de criança, festa a fantasia), à razão do convite (convidado para provocar ciúme no antigo namorado) e à forma da acolhida (desconhecidos que o chamam pelo nome) (II, p. 346). As do tipo VIII tratam também das transformações do crer e do saber. Em todas as redações, o sujeito deve realizar um fazer persuasivo durante a festa, para fazer parecer verdadeiro e para fazer o outro crer nesse parecer. No grupo VIII, as redações focalizam essencialmente o fazer persuasivo do sujeito e o fazer interpretativo do outro. Abordam a questão da veridicção (por exemplo, o rapaz está perto do bar e é confundido com o garçom e assim continua a narrativa) (II, p. 351352).

As redações do tipo XI $(8,23 \%)$ fazem do narrador um observador que critica o outro, ri de seus vexames. Em algumas, em lugar de criticar, elogia o observado (II, p. 355).

Finalmente, com 5,24\% do total, há as redações que têm um final inesperado (grupo VI) ou aquelas que fazem uma comparação explícita entre a festa e a vida e a morte (grupo X). 
10 (esp.)

$12-26$

mai.

2020

Diana Luz Pessoa de Barros, em sua análise narrativa, como já deixamos entrever, não estuda apenas esses tipos, mas examina também os subtipos em cada um deles. Por exemplo, as redações do tipo II, as de sucesso, dividem-se em dois subtipos. O primeiro (75\%) narra a história de um sujeito que está insatisfeito e tenso em casa; recebe um convite para uma festa; vai, animado, mas um tanto preocupado por não conhecer ninguém; tem um mau começo de festa, mas tudo acaba dando certo e o sujeito fica satisfeito e confiante. O subtipo II (25\%) narra que um sujeito, contente e relaxado, recebe um convite que lhe causa preocupação, principalmente por não conhecer ninguém que vai estar na festa; acaba, porém, aceitando ir e, depois de um momento inicial ruim, consegue o que deseja e fica, de novo, satisfeito e confiante. A diferença entre os dois subtipos está na sequência inicial (II, p. 315-316).

Na análise narrativa, a pesquisadora estudou também as más formações narrativas e a questão da originalidade e da criatividade. Os problemas de organização narrativa dizem respeito à pressuposição lógica que liga programas e percursos e à organização modal da existência e da competência do sujeito (II, p. 372). Uma ocorrência do primeiro é o de um sujeito que não pode, mas faz: por exemplo, a fumaça era tanta que não permitia ver qualquer pessoa, mas o sujeito encosta numa parede e fica observando os tipos que estavam na festa (II, p. 374); um caso do segundo tipo é o de um sujeito que não tem nenhuma expectativa e fica decepcionado.

Diana Pessoa de Barros discute a questão da originalidade pelas notas, para verificar a correspondência, existente ou não, entre boas redações e frequência de tipos narrativos. Com esse exame, descarta a correlação entre frequência de tipo narrativo e originalidade, bem como afasta uma definição estatística de originalidade, que consideraria o menos frequente melhor. A originalidade é decorrente da integração dos diferentes níveis, isto é, "é do jogo das múltiplas opções sintáticosemânticas fundamentais, narrativas, discursivas e textuais que resulta um texto único" (II, p. 393). Assim, a originalidade não provém das estruturas narrativas ou discursivas, mas de sua integração.

Passa, em seguida, para a análise discursiva das redações. Elas não fazem uso variado de elementos da sintaxe discursiva. Todos os textos usam a debreagem actancial enunciativa, o que é uma resposta direta à proposta de redação: Suponha que você foi [...] convidado... A debreagem temporal é enunciva, valendo-se dos tempos do passado. A espacial opõe o aqui ao lá. A programação espacial e a aspectualização são rotineiras. A técnica argumentativa usada é a das argumentações fundadas no caso 
particular: a ilustração, o exemplo ou o modelo. Na maior parte dos casos, emprega-se a argumentação pelo exemplo. "A festa é apresentada como um caso particular que conduz à formulação de um saber mais geral, como um exemplo de que se extrai uma lição explicitamente manifestada, em geral, na sequência final" (II, p. 411-412).

Há casos de erros na argumentação, sobretudo ocorrências de inadequação do caso particular à generalização, desde exemplos insuficientes para comprovar a regra a casos que não se relacionam à generalização proposta ou mesmo situações particulares que conduzem a generalizações contrárias às apresentadas. Por exemplo, o sujeito não gostou das pessoas a que foi apresentado na festa, afastou-se delas, integrou-se a outro grupo e concluiu que se deve ter amizade com todas as pessoas (II, p. 416-417).

Os textos trabalham com a relação conhecido vs. desconhecido. $80 \%$ deles desenvolvem percursos temáticos relacionados ao saber e ao não saber. O primeiro é o termo positivo e o segundo, o negativo. A partir desses valores, as redações contam com os percursos temáticos de: a) familiaridade (familiar vs. estranho); b) amizade (amigo, conhecido vs. estranho, desconhecido); c) rotina (rotineiro vs. inesperado); d) regra (prescrito vs. proibido); e) normalidade (normal vs. anormal, louco, misterioso, fantasioso); f) atividade vs. passividade (II, p. 419-420). Diana Pessoa de Barros vai estudar cada um desses percursos, mostrando como cada um deles é visto e figurativizado. Mostra, por exemplo, que:

enquanto a oposição entre a familiaridade e a não familiaridade determina a busca de novos amigos e a passagem, em geral, malsucedida, à idade adulta, a relação entre classes diferentes acarreta, nas redações, a procura de ascensão social (II, p. 427).

Esse é um tema muito frequente nas redações. Estudados os diferentes temas, conclui-se que duas configurações temáticas básicas ocorrem nas redações, a primeira ligada ao saber-conhecer, a segunda, ao fazer-participar, manifestadas nos percursos temáticos, sobretudo, da familiaridade (passagem da vida familiar à vida social adulta), da ascensão social, da aventura (bem menos frequente) e da passividade. Na maioria dos textos, os percursos não são claramente desenvolvidos, não há reiteração dos traços que determina uma linha temática completa (II, p. 436).

Há três grandes configurações figurativas, a do convite, a da vida no lar e a da festa, que nos diferentes percursos temáticos assinalados, explicam o investimento figurativo de quase todas as redações. 
10 (esp.)

$12-26$

mai.

2020

Os percursos figurativos raramente são bem construídos, instaurando uma isotopia figurativa. Cita-se, entre os mais bem arquitetados, uma redação que cria o seguinte percurso para o tema do requinte intelectualizado e ultrapassado: "portas de carvalho, olhos míopes e papudos, tilintar de xícaras, madonas, sorver o chá, pequenos goles sonoros, lunetas, trêmulas mãos, cachorro de loiça chinesa, tapete persa, loiça de Cantão, mão rugosa, sabre prussiano, parede carmesim" (II, p. 441). Mostra-se também uma isotopia bem construída para o tema da vulgaridade, da cafonice: "música de Agnaldo Timóteo, alto volume, tapa nas costas, cerveja preta, sanduíche de pernil, risadas altas, piadas sem graça, tangos e boleros com muito sentimento, ar de astro de televisão, terno branco, cravo vermelho na lapela" (II, p. 441).

Diana Pessoa de Barros debruça-se sobre as figuras da festa. Depois de mostrar como Caillois e Bakhtin apresentam a festa, a pesquisadora aponta que as descritas pelos vestibulandos perderam a função de renovação do mundo e da vida social. Nelas, o sujeito, relegado comumente à posição de observador passivo, não participa da festividade. A capacidade de rir de si mesmo está ausente das festas dos vestibulandos. Todos se levam muito a sério. A verdade, portanto, estabelece-se de uma vez por todas, imutável e definitiva (II, p. 453). Não há a ambivalência carnavalesca e, por isso, tem-se uma denúncia de caráter moral ou sócio-político nas redações de observação e de crítica, ou repetem-se verdades e discursos prontos, na maior parte dos textos (II, p. 454). As festas das redações são festas burguesas, esvaziaram-se dos objetivos de recriar a vida social e ficaram sem significado. Os erros cometidos pelos vestibulandos mostram que eles não conhecem essas festas. Elas foram aprendidas, sobretudo, nas telenovelas (II, p. 456). Para fazer essa afirmação, a pesquisadora comparou as festas retratadas nas redações com festas descritas nos Boletins de Programação da Globo do período. As festas neles descritas poderiam figurar entre as redações do vestibular (II, p. 459).

As figuras de expressão são raríssimas. Das 16 redações que tiveram nota dez (quatro) ou nove (doze), só duas têm alguns recursos de expressão (II, p. 446).

A estrutura fundamental estabelece-se basicamente na oposição natureza vs. Cultura:

Ora, a família é considerada natural, com suas regras e normas da natureza, em oposição ao artificialismo e à formalidade cultural da festa, ora, na festa, aparecem instintos animalescos, 
não controlados, próprios da natureza, que se distinguem do domínio e da calma do homem que vive, culturalmente, em família. (II, p. 438).

No último capítulo, Diana Pessoa de Barros estuda as relações entre o discurso dos vestibulandos e o contexto sócio-histórico, concretizando sua proposta de fazê-lo por meio da intertextualidade.

O contexto situacional será definido por dois tipos de texto: a proposta de redação, conversas com professores de cursinho sobre a imagem que o vestibulando faz do examinador e trabalhos sobre a redação no vestibular. O contexto interno foi delimitado pelo conjunto de redações, ou seja, cada redação contextualiza as outras e é contextualizada por elas. O contexto externo é dado pelo questionário informativo que o vestibulando preenche no momento da inscrição. Com ele, pretende-se determinar a inserção social dos vestibulandos e a relação entre classe social e elementos discursivos (II, p. 464-465).

O contexto interno permitiu estabelecer os tipos distintos de redações e, principalmente, verificar sua mesmice. O contexto situacional mostrou que o sujeito "tentou realizar o que lhe fora pedido, ou melhor, o que ele entendeu que lhe fora pedido, para não ser reprovado" (II, p. 467). Duas razões levaram o vestibulando à interpretação feita da proposta: de um lado, a concepção que ele tem da linguagem, do ato de redigir, da escola, do vestibular e a imagem que faz do examinador; de outro, a falta de domínio da norma culta, o desconhecimento das características da modalidade escrita e a ignorância da organização discursiva. Para eles, o ato de redigir é uma tarefa escolar, que deve ser cumprida com uma estratégia de preenchimento de um esquema formal previamente dado ou inferido. O examinador é "conservador, cuidadoso com as questões de ortografia, capaz de apreciar um texto mais 'erudito', com um fraco por palavras difíceis, um tantinho moralista e preocupado com o bem, o certo, a ordem" (II, p. 471). Algumas redações veem o examinador como um "sujeito 'avançado', envolvido em política, preocupado com os temas sociais" (II, p. 471). O ato de escrever é entendido como a reprodução de modelos vistos na escola, em sua maioria textos literários utilizados nos livros didáticos, que dão ao aluno pedaços de frases, recursos figurativos e expressivos e assim por diante. Os alunos desconhecem as condições de produção do discurso. Três aspectos, como já foi dito, podem ser lembrados: a questão da norma culta; a relação entre fala e escrita; o problema do discurso. Diana vai propor que a escola se dedique à questão da variação linguística, ensine a diferença entre fala e escrita, bem como a "gramática" do discurso. 
10 (esp.)

$12-26$

mai.

2020

Para estabelecer a classe social de cada vestibulando, Diana Luz Pessoa de Barros, com base em trabalhos de Paul Singer e Emir Sader, levou em conta os dados do questionário informativo sobre renda familiar, ocupação do pai e ocupação da mãe. Discute as dificuldades e os problemas dessa proposta, principalmente o fato de o questionário não permitir saber a posição na ocupação, ou seja, se o indivíduo é empregado, autônomo ou empregador.

A partir desses dados, a pesquisadora levou em conta as seguintes classes ou frações de classe: burguesia empresarial, burguesia gerencial (altos quadros da burocracia e da tecnocracia), pequena burguesia tradicional (pequenos proprietários, profissões liberais, científicas, técnicas e artísticas, trabalhadores agrícolas ou de serviço que exercem o trabalho de forma autônoma); pequena burguesia assalariada (trabalhadores de ocupações administrativas e burocráticas, pequenos servidores civis e militares, trabalhadores do comércio, professores e técnicos) e classe operária (II, p. 481-483). Mais de $80 \%$ dos vestibulandos pertencem à burguesia e à pequena burguesia, classes a que pertencem $24,3 \%$ da população brasileira. Deve-se notar, sobretudo, a grande quantidade $(67,6 \%)$ de membros da pequena burguesia entre os vestibulandos (II, p. 498).

Relacionando os percursos temáticos e figurativos e as classes sociais, a pesquisadora notou várias correlações, entre as quais talvez a mais importante é a de que entre os filhos de operários e da burguesia empresarial não aparece o tema da ascensão social, que, no entanto, é avassalador nas redações dos oriundos da pequena burguesia. Os temas confusa e vagamente desenvolvidos nas redações identificam-se com o que Décio Saez vai chamar "consciência média", ou seja, a consciência das camadas médias da população. Por exemplo:

o desejo de ascensão social e o medo da proletarização marcam quase todas as redações e caracterizam sujeitos convictos de ascender na escala social. Importa ser convidado, bem aceito e bem recebido pelos ricos e compartilhar sua casa e seus valores, ao mesmo tempo que se teme a identificação com o trabalhador manual (é, pelo menos, desagradável ser confundido com o garçom ou o encanador) e a vulgaridade de certas festas 'populares' (II, p. 515).

Reiteram-se nas redações os valores pequeno-burgueses, porque esse é (ou era, quando a tese foi escrita) o público de nossas universidades. A inserção na classe social, como recurso obrigatório para a caracterização sócio-ideológica do sujeito da enunciação, é, nesta 
tese que estamos examinando, o elemento central para estabelecer as relações entre discurso e contexto sócio-histórico. Vejam que, se a tese tivesse sido publicada integralmente, essa contribuição de Diana Luz Pessoa de Barros não ficaria na sombra.

Um dia, alguém que trabalha com análise do discurso me perguntou se a semiótica brasileira reproduzia a semiótica francesa ou tinha uma contribuição original para ela. Minha resposta foi que, além de contribuições teóricas para o desenvolvimento do modelo (por exemplo, tudo o que diz respeito às paixões e à sintaxe e à semântica do discurso), havia uma característica que diferençava a semiótica brasileira da semiótica francesa: a preocupação das relações entre o discurso e o contexto sócio-histórico.

Isso foi algo que os franceses puseram entre parênteses numa compreensão, como se disse, um tanto estreita do princípio da imanência. Hoje, alguns semioticistas franceses começam a enunciar essa problemática, cheios de dedos com a questão do princípio da imanência. Veja-se, por exemplo, que Eric Landowski, em seu "Pequeno manifesto semiótico", propõe que a semiótica não tenha um olhar neutro para as práticas dominantes de sentido, mas que o semioticista se engaje "num trabalho, em última instância, político, visando, por meio das relações de sentido, à transformação das relações sociais e das formas de vida" (2016, p. 1). Afirma o autor que "nesse sentido, fazer semiótica é exatamente fazer política" (2016, p. 3). Mas Landowski, com muito cuidado com o princípio de imanência, alerta para o fato de que a posição que defende "pode, certamente, ser considerada uma atitude extrassemiótica, de ordem política ou inspirada numa ética" (2016, p. 4), mas que, de fato, sua posição "parece-lhe respeitar a esfera de coerência teórica da semiótica" (2016, p. 4), pois "ela decorre, salvo ilusão, da própria teoria, de seus princípios de coerência interna" (2016, p. 1).

Há mais de trinta anos, com uma compreensão mais alargada do princípio de imanência, Diana Luz Pessoa de Barros deu uma contribuição importante para o estudo das relações do sujeito com o contexto sócio-histórico. Diana olha as coisas que existem e quer explicá-las, mas, principalmente, sonha com as que nunca existiram e faz que existam. Essa deve ser a atitude de um pesquisador: olhar para as coisas que existem e perguntar: "Por quê?", mas, principalmente, sonhar com as que nunca existiram e perguntar: "Por que não?". 
v. 10 (esp.)

$12-26$

mai.

2020

\section{Referências}

BARROS, Diana Luz Pessoa de1985). A festa do discurso: teoria do discurso e análise de redações de vestibulandos. 1985. 2 volumes. Tese de LivreDocência, Faculdade de Filosofia, Letras e Ciências Humanas. Universidade de São Paulo, São Paulo, 1985.

BARROS, Diana Luz Pessoa de. Teoria do discurso. Fundamentos semióticos. São Paulo: Atual, 1988.

LANDOWSKI, Eric. Petit manifeste sémiotique en l'honneur et à l'attention du camarade sociologue Pekka Sulkunen. In: Beyond Sociological Imagination. Festschrift in Honour of Professor Pekka Sulkunen. Helsinki: Unigrafia, 2016. 